\title{
Kadın Girişimcilerin COVID-19 Pandemi Sürecindeki Girişimcilik Algıları: Kayseri ve Gaziantep Örneği*
}

\author{
Entrepreneurship Perceptions of Women \\ Entrepreneurs During the COVID-19 Pandemic: \\ The Case of Kayseri and Gaziantep
}

\author{
Tuba Büyükbeşe** \\ Tuğba Dikbaş*** \\ Irfan Doğan $* * * *$
}

\begin{abstract}
$\ddot{O}_{z}$
Bu çalışmanın amacı Covid-19 küresel salgınında kadın girişimcilerin, pandemi öncesi ve pandemi sürecinde girişimcilik algılarının belirlenmesi ve karşılaştırılmasıdır. Çalışmada ilk olarak Kayseri ve Gaziantep illerinde farklı sektörlerde işletmeleri olan kadın girişimcilerin pandemi öncesinde ve pandemi sürecinde girişimcilik algılarında (Kontrol Odağı, Kendine Güven, İletişim, Motivasyon boyutlarında) farklılık olup olmadığı test edilmiş, sonrasında kadınların demografik özelliklerine göre girişimcilik algılarında (alt boyutlarında) anlamlı değişim olup olmadığı araştırılmıştır. Belirlenen amaçlar doğrultusunda nicel araştırma yöntemiyle tasarlanan araştırmada, veri toplama yöntemi olarak çevrim
\end{abstract}

* Bu araştırma makalesi 27-28 Mayıs 2021 tarihinde 2nd International Economics and Business Symposium'da (Effects of Covid-19 In All Dimensions) Tuğba Dikbaş tarafından sözlü bildiri olarak sunulmuştur.

** Prof. Dr., Hasan Kalyoncu Üniversitesi, İ́SBF, İşletme Bölümü, tuba. buyukbese@hku.edu.tr ORCID: 0000-0003-4174-9870

*** Bilim Uzmanı, Hasan Kalyoncu Üniversitesi, SBE, tugbaranadikbas@gmail. com ORCID: 0000-0003-0966-2353

**** Araştırma Görevlisi, Gümüşhane Üniversitesi, SBF, Sosyal Hizmet Bölümü, irdogan07@gmail.com ORCID: 0000-0002-1671-7204

Başvuru: 05.08.2021

Kabul: 20.09.2021

DOI: $10.21798 /$ kadem.2022.58
This work is licensed under the Creative Commons Attribution 4.0 International License.

Cite this article as: Büyükbeşe, T., Dikbaş, T. ve Doğan, I. (2021). Kadın Cirişimcilerin Covid-19 Pandemi Sürecindeki Girişimcilik Algıları: Kayseri ve Gaziantep Örneği, Kadem Kadın Araştırmaları Dergisi, Vol. 7, No. 2: 219-247 
içi anket yönteminden yararlanılmış, Girişimcilik Algısı veri toplama aracı kullanılmıştır. Çalışma 211 işletme sahibinin katılımıyla yürütülmüştür. Elde edilen veriler SPSS 21.0 programı kullanılarak analiz edilmiştir. Kadın girişimcilerin pandemi öncesi ve pandemi sürecinde girişimcilik algıları, bireysel girişimciliğe ilişkin kontrol odakları, bireysel girişimciliğe ilişkin kendine güvenleri, bireysel girişimciliklerine ilişkin iletişimleri ve bireysel girişimciliklerine ilişkin motivasyonları arasında anlamlı bir fark bulunmuştur.

Anahtar Kavramlar: Girişimcilik Algısı, Covid-19, Kadın Girişimciler

\begin{abstract}
The purpose of this study is to determine and compare the entrepreneurship perceptions of women entrepreneurs before and during the global Covid-19 pandemic. In the study, firstly, it was tested whether differences arose in the entrepreneurship perceptions (in the dimensions of Focus of Control, Self-Confidence, Communication, and Motivation) of women entrepreneurs who have businesses in different sectors in Kayseri and Gaziantep provinces. This was followed by an investigation of whether there was a significant change in the entrepreneurship perceptions (in their sub-dimensions) of women in compliance with their demographic characteristics. This study is designed with a quantitative research method in line with the specified purposes, and it uses online survey as a data collection tool. Research was conducted with the participation of 211 business owners. The data obtained was analyzed using the SPSS 21.0 program. A significant difference was found between the perceptions of entrepreneurship by female entrepreneurs before and during the pandemic, their control focus on individual entrepreneurship, their self-confidence in individual entrepreneurship, their communication regarding their individual entrepreneurship, and their motivations for their individual entrepreneurship.
\end{abstract}

Keywords: Perception of Entrepreneurship, Covid-19, Women Entrepreneurs

\title{
Extended Abstract
}

The aim of this study is to determine and compare the entrepreneurship perceptions of women entrepreneurs in the Covid-19 global epidemic, before and during the pandemic.

The study seeks to answer the question of whether there are any differences before and during the pandemic in the perception of entrepreneurship (based on the dimensions of focus of control, self-confidence, 
communication, and motivation) of women entrepreneurs who have businesses in different sectors in Kayseri and Gaziantep.

The pandemic was announced by the World Health Organization on March 11, 2020, and life came to a standstill all over the world (WHO, 2020). It has affected the whole world in multiple areas, such as economy, health, education, etc. (Bacq, Geoghegan, Josefy, Stevenson and Willams, 2020). In the guidelines prepared in the fight against Covid-19 since the outbreak began (WHO, 2020; OECD, 2020; T.C. Ministry of Health, 2020) and in response to the increase in the spread of the virus in hospitals, schools, shopping malls, workplaces, and public places, various closures, flexible working hours, and remote working routes have been adopted within the scope of the measures. The closures have been explained as measures taken to prevent deaths and new cases and to decrease the number of cases in the fight against the pandemic (T.C. Ministry of Health, 2020). Turkey has prepared various social and economic support programs to increase public welfare in this process (Small and Medium Enterprises Development and Support Administration [Kosgeb], 2020; T.C. Official Newspaper, May 21, 2021). According to the Business for Goals Platform (2020, p.20), which is one of the first studies on the impacts of the epidemic, female entrepreneurs have been the most affected by the inability to carry out their economic activities and to sustain their perceptions of individual entrepreneurship in the fight against Covid-19. According to the findings of the surveys collected online from 619 microenterprises in March and May to investigate the effects of the Covid-19 crisis on businesses in the Business for Goals Platform (2020 p.20), women entrepreneurs are affected at a much higher rate than men.

The entrepreneurial activities of women generally consist of micro enterprises. Female entrepreneurs are those who turn their ideas into entrepreneurial projects, see opportunities to put their skills to work, and seek flexible working hours, economic independence, being an employer of their own, and achieving success (Brush, De Bruin \& Welter, 2009, p.8; Yadav \& Unni 2016: 1).

In research on determining characteristics of entrepreneurial individuals and the relationship between entrepreneurship and character; character traits like risk-taking, self-sufficiency, aggressiveness, ambition, desire for independence, success-orientedness, motivation to achieve, tolerance to uncertainty, creativity and innovation, courage, effective communication, internal control, forward thinking, credibility, self-confidence (Arıkan, 2004; Collins, Hanges \& Locke, 2004; Curth, 2011; Fuller \& Marler, 2009; Gartner, 1988; Gorman, Hanlon ve King, 1997; Korunka, Frank, Lueger \& Mugler, 2003; Rauch \& Frese, 2007; Shahhosseini, Kavousy, Shirsavar, \& Ardahaey, 2011; Shaver \& Scott, 1992; Stewart \& Roth, 2007; Utsch, Rauch, Rothful, \& Frase, 1999) emerge at the forefront. 
The study group of the research consists of 250 women entrepreneurs operating in the provinces of Kayseri and Gaziantep. The online survey was sent to 250 women entrepreneurs, including owners of restaurants, cafes, etc. (39) hairdressers, beauty salons, etc. (15), education centers, kindergartens, dormitories, elderly care centers, etc. (76), gyms (13), cleaning services (53), jewelry, cosmetics, and perfumery shops, etc. (15). A total of 211 female entrepreneurs with micro-enterprises returned the surveys, and these were evaluated within the scope of the research.

The reason for the selection of these areas of activity is to determine the extent to which female entrepreneurs are affected in cases of restrictions and closures during the pandemic. Convenience sampling method was used within the scope of the research. Of the online questionnaires sent to 250 women entrepreneurs, 211 were returned and included in the study. Quantitative research method was used in the study. Online surveys were used as a data collection tool. The survey consists of 2 parts. In the first part of the survey, questions about the socio-demographic information of the participants are included. In the second part, there are questions about the perceptions of entrepreneurship of female participants before and during Covid-19. The necessary permissions for the research were obtained from Hasan Kalyoncu University (The Date and Number of Documents: 22.04.2021 - E.2104220003). The scale permission used for the survey was used electronically with the permission of the authors/s.

$70.6 \%$ of female entrepreneurs are married and $29.4 \%$ are single; $52.1 \%$ are ages $26-33$ and $47.9 \%$ are between the ages of 34 and 41 . It was found that $73.5 \%$ have a high school degree, $26.5 \%$ have a university degree, while $48.8 \%$ have $2-3$ children, $27.0 \%$ have 1 child, and $24.2 \%$ do not have children. $54.5 \%$ of the participants owned a business for 3 years, followed by those who owned the business for 2 years with a rate of $23.7 \%$, and $21.8 \%$ owned the business for 4 years. When the enterprises were examined, it was found that $36.0 \%$ carried out activities such as education and social service, $25.1 \%$ offered cleaning services, and $18.5 \%$ consisted of as restaurants, home cooking places, cafes, etc. $43.1 \%$ of the participants have 2 employees, $38.4 \%$ have 3 employees and $18.5 \%$ have 1 employee. A significant difference was found between the participants' perceptions of entrepreneurship before and during the pandemic, their control focus on individual entrepreneurship, their selfconfidence in individual entrepreneurship, their communication regarding their individual entrepreneurship, and their motivations for their individual entrepreneurship.

The biggest difference between entrepreneurship perceptions was found between motivation and control focus. The negative psychological 
mood created by the pandemic process in most people may have caused a lack of motivation. The pandemic may have caused a decrease in the control focus of female entrepreneurs by creating unstable conditions and increased uncertainty that develop against the will of entrepreneurs. Therefore, Covid-19 has had an impact on the perceptions and dimensions of individual entrepreneurship of female entrepreneurs. It can be said that their perceptions of individual entrepreneurship were negatively affected by this process. The aim of this research is to investigate the individual perceptions of female entrepreneurs during the Covid-19 pandemic. There have been studies related to entrepreneurship and the Covid-19 outbreak, but there is very little work on the individual perceptions of women entrepreneurs in the Covid-19 process. Studies on the differentiation of the characteristics of entrepreneurs, especially female entrepreneurs (Manolova, Brush, Edelman \& Elam, 2020; Mathew, Deborah, Karonga \& Rumbidzai, 2020; Jaim 2020; Grandy, Cukier \& Gagnon, 2020) support the literature and findings of this study. The findings from research about the characteristics of entrepreneurial female individuals before Covid-19 single out control focus (Brockhaus, 1980; Korunka et al., 2003), motivation (Collins et al., 2004; Johnson, 1990; Stewart \& Roth support this research, which includes 2007) communication (Gorman et al., 1997) planning (McCarthy \& Leavy, 1999), self-confidence (Gartner, 1988) and selfdiscipline (Shahhosseini et al., 2011). It is seen that the pandemic epidemic negatively affects the perceptions of women who have not completed 5 years of microscale business experience, new entrepreneurs, and business owners within the scope of research. In addition to state support for female entrepreneurs, NGOs also offer support (Women Entrepreneurs Association, [Kagider] 2021; Kosgeb, 2020; Women Entrepreneurs Association, [Kedv] 2021). However, these support programs need to be increased. It may be recommended that these supports be offered both financially and through needs-oriented trainings such as crisis management, stress management, and e-commerce. It is thought that the subsequent qualitative conduct of this research will help future studies.

\section{GİRİŞ}

Covid-19 virüsüyle mücadelede salgının başladığı günden bugüne kadar hazırlanan rehberlerde (WHO, 2020; OECD, 2020; Sağlık Bakanlığı, 2020) insanların toplu hâlde bulunduğu ortamlar hastaneler, okullar, alışveriş merkezleri, iş yerleri, kamusal alanlarda virüs yayılımının artış göstermesiyle önlemler kapsamında çeşitli 
kapanma, esnek çalışma, uzaktan çalışma yollarına gidilmiştir. Söz konusu tedbirler yeni vakaların ortaya çıkmaması, pandemiyle mücadelede vaka sayılarının azalması ve vefatların engellenmesi için alınan önlemler olarak açıklanmıştır (Sağlık Bakanlığı, 2020). Türkiye de bu süreçte "Ekonomik İstikrar Kalkanı Paketi" adıyla sosyal ve ekonomik bir yardım paketi hazırlamıştır (KOSGEB, 2020a). Covid-19'un olumsuz tesirlerini iyileştirmek ve kamu refahındaki boşlukları doldurmak amacıyla "Esnaf ve Sanatkârlar ile Gerçek Kişi Tacirlere Korona Virüs Salgını Nedeni ile Verilecek Hibe Desteği”" (Resmi Gazete, Mayıs 21, 2021) sağlanmıştır.

Kadın girişimciler Covid-19 ile mücadelede ekonomik faaliyetlerini yerine getiremeyen, dolayısıyla sürdürülebilirliklerini icra edemeyen ve bireysel girişimcilik algıları olumsuz şekilde etkilenen en büyük kesimlerden biri olmuştur. Salgının tesirlerine ait ilk çalışmalardan biri olan Hedefler için İş Dünyası Platformu'nda (2020: 20) Covid-19 krizinin işletmeler üzerindeki tesirlerini araştırmaya yönelik mart ve mayıs aylarında 619 mikro işletmeden çevrim içi olarak toplanan anketlerin bulgularına göre \%34'ünü kadın çalışanların oluşturduğu kadın girişimcilerin, erkeklerden çok daha yüksek oranda etkilendiği ifade edilmektedir.

$\mathrm{Bu}$ araştırma kapsamında, Covid-19 salgınında özellikle kadın girişimcilerin karşı karşıya kaldıkları, kazanç elde edememe, işletme faaliyetlerine devam edememe riskleri, sosyal ihtiyaçların karşılanması, sosyal değişim yaşadıkları sürece odaklanamama, planların gerçekleşmemesi, motivasyon düşüklüğü vb. kadın girişimcilerin bireysel algılarının pandemi öncesi ve pandemi sürecinde değişip değişmediği araştırılmıştır.

\section{TEORİK ÇERÇEVE}

\subsection{Kadın Girişimcilik}

Tarihsel olarak kadın iş gücüne katılımdaki artış genellikle 20. yüzyılda yaşanan sosyal değişimlerin ve ekonomik büyümenin en önemli sebeplerinden biri olarak kabul edilebilir. 1980'li ylllardan sonra girişimcilik kavrayışı hızlı bir büyüme göstererek ekonomide 
üretim faktörü olarak yerini almış (Czarniawska-Joerges ve Wolff, 1991: 536), tüm ülkelerde çalışanların nüfus özelliklerinde değişime neden olmuş ve bu değişimden kadınlar da önemli oranda etkilenmiştir. Sanayi Devrimi’nden önce kadının misyonu konut işlerini ve aileye bakım işlerini oluştururken, girişimciliğin kazandığı ivmeyle kadının iş gücüne katılımı ve ailenin geçimine katkısı artmıştır (Mitchell, 1962; Baumol, 1968: 65; Low ve MacMillan, 1988: 151152). Ekonomik büyüme ve kalkınmanın itici gücü olan girişimcilik (Paksoy, Özbebek ve Gül, 2019: 978) alanında kadın girişimciler her geçen gün artmaya devam etmektedir.

Türkiye'de kadın bireylerin girişimcilikleri 1990'lı yılların sonunda büyük önem kazanmıştır (Arat, 1996: 404). Kadın bireylerin girişimci faaliyetleri genel olarak mikro işletmelerden oluşmakta olup kadın girişimciler; sahip oldukları yetenekleri kullanabilme, esnek çalışma, ekonomik bağımsızlık, kendi kendinin işvereni olmak, beşerî başarı elde etme gibi firsatları gören ve fikirlerini girişimciliğe dönüştüren bireylerdir (Brush, De Bruin ve Welter, 2009: 8; Yadav ve Unni 2016: 1).

Çelebi (1993), kadın girişimciyi kendi işlerinin sahibi, tek başına çalışan veya işçi çalıştıran, mal ve/veya hizmet üreten, bu süreçleri geliştirip satan, acil iş problemlerini çözebilen, yeni kaynaklar arayabilen, alanına uyum sağlayabilen ve deneyim kazanmaya çalışan bir kadın olarak tanımlar (Şekerler, 2006). İlter (2008: 70) ise kadın girişimcileri, genel anlamda ev harici bir ortamda veya birden fazla iş yerinde kendi namına veya ortaklık şeklinde mal sahibi veya hizmetin yapılması, pazarlaması ve tüm ticari işlemleri hakkında kararlar alan, müessese ve tüzel kişilerle kendi namına ilişkiler kuran ve bu ilişkilerden kazanç elde eden kişi olarak tanımlar.

Türkiye'de kadın girişimcilik kültürünün gelişmesi için KOSGEB, İŞKUR, Çalışma ve Sosyal Güvenlik Bakanlığı, Sivil Toplum Kuruluşları, kadın girişimciliğini iş birliği yoluyla destekleyen ve teşvik eden bir alan olarak önemli katkılar sağlamaktadır. Öte yandan kadın girişimciliğinin desteklenmesine yönelik girişimcilik eğitimleri, mikro finans uygulamalarının geliştirilmesi, finansal 
kaynaklara erişim konusunda bilgilendirme ve rehberlik hizmetleri verilmektedir (Resmî Gazete, Temmuz, 04, 2017).

\subsection{Girişimcilik Algısı}

Girişimcilik algısı, toplumu oluşturan bireylerin girişimciliğe yönelik tutumları ve harekete geçme eğilimleri olarak tanımlanabilir. Bir başka tanıma göre ise girişimcinin iş planının oluşturulmasına ve uygulanmasına rehberlik eden psikolojik süreçtir (Kahya ve İmamoğlu, 2015: 144). Girişimcilik algısı, bir işe başlama kararında önemli bir rol oynar. Bir işin planlanması ve uygulanması sürecinde bireysel özellikler ve donanımlar farklılık göstermektedir. Aynı zamanda bireylerin yaşam döngülerinde de farklılıklar vardır (Linan ve Chen, 2009: 593).

Alanyazında girişimcilerin algılarını etkileyen durumlarla ilgili farklı paradigmalar önerilmiştir. Bu çalışmalar incelendiğinde üç ana faktörün öne çıktığı görülmektedir. Bunlar; girişimci kişisel özellikler, demografik özellikler ve çevresel faktörler (Şeşen ve Basim, 2012:22).

Girişimcilik algısı bireyin sosyal katılım ve fırsatları keşfetmesi, bu olgulara yönelik geliştirdiği yorum, anlam ve hislerden oluşmaktadır. Dolayısıyla bu algılar, çevredeki fırsatların hissedilebilmesinin yanında, iletişim, kontrol odağı, motivasyon, kendine güven, planlama, öz disiplin oluşumu açısından da önem taşımaktadır (Koh, 1996). Girişimcilik algısında iletişim; açık iletişim kurma özelliği, problemleri basitlikle çözebilme yeteneğine sahip olma, güvende hissetmek, etrafındaki kaynakları iyi değerlendirebilme, insan ilişkilerinde başarılı olmak ve insanların desteğini kazanmak, ekip çalışmalarına yatkın olma, müsamahalı olma, özverili olma, kararlı olma, inovasyona açık olma, yaratıcı olma, bağımsızlık, rekabetçi olmak olarak açıklanmaktadır (Aşkın ve Barış, 2016). Girişimciliği etkileyen bir diğer değişken kontrol odağı olarak adlandırılmaktadır. Kişinin kazanımları, kendi tutumları, ödül ve cezalar hakkındaki algıları neticesi olduğuna inanmasıdır (Rotter, 1966). Kendine güven; kişinin hedef ya da kendi işinde alabildiği sorumluluğu başaracağına 
inanması, ihtiyaç duyduğu yeteneğe sahip olduğuna dair inancı ifade eder (Bowman, 1999). Öz disiplinli girişimciler ise çalıştıkları ortamlarda diğer insanlara karşı naziktirler, rekabet etmek yerine iş birliği yapmaya isteklidirler; tüm vazifeleri sorumluluk bilinci içinde hedeflere ulaştırmak için çalışırlar. Ekip çalışmasına yatkın olan bu kişiler çalışma arkadaşlarına güven duyarlar (Forrester ve Tashchian, 2010: 44). Motivasyon ve planlama; inovasyon, kontrol gereksinimi, galibiyet gereksinimi ve özgür olma, kazanma arzusu, aile bireylerinin mutluluğunu gerçekleştirme isteği, yeni beceriler geliştirmek, iş yerinin hedeflerine ulaşma sürecinde belirleyici rol oynamasıdır (Carland, Hoy, Boulton ve Carland, 1984: 354-359).

Hisrich ve Peters'a (2002) göre kadın girişimcilerin özelliklerini Motivasyon.: Bir amacı gerçekleştirmeye yönelik başarı edinimi, bir işi tek olarak yapmak, özgür olmak; Girişimde Bulunma Nedenleri: İşten kaynaklanan sorunlar karşısında hayal kırıklığı, alanına ilgi veya o alanda firsat yakalamak; Fon Kaynakları: Kişisel varlık ve birikim, kişisel borçlar; Meslekî Geçmişleri: İş alanında tecrübe, orta düzey yönetimsel tecrübe, hizmet sektörüyle ilgili meslekî özgeçmiş; Kişisel Özellikleri: Esneklik ve tolerans, amaç odaklılık, üretken ve realist olmak, orta düzey öz güven, hevesli ve enerjik olma sosyal ve ekonomik çevreyle uğraşabilme mücadele yeteneği olarak açıklar.

Özgeçmişleri: 35 ve 45 yaş aralı̆̆ında işletme kurmak, babasının kendi işine sahip olması, üniversite mezunu olmak, ailede ilk çocuk olmak; Destek Olan Gruplar: Yakın arkadaşlar, eş, aile, profesyonel kadın cemiyetleri; Kurdukları Girişimin Türü: Hizmet sektörü olarak tanımlanmaktadır.

Bilhassa kadınların iş gücüne katılımı üzerine, girişimci bireylerin karakter özellikleri konusunda literatürde oldukça fazla araştırma olduğu görülmektedir. Girişimci bireylerin karakter özelliklerini belirlemeye ve girişimcilik ile karakter arasındaki ilişkiye yönelik araştırmalarda; risk alma, öz yeterlik, agresiflik, hırs, bağımsızlık isteği, başarı odaklılık, başarmaya yönelik motivasyon, belirsizliğe karşı tolerans, yaratıcılık ve yenilikçilik, cesaret, etkili 
iletişim, iç kontrol, ileri görüşlülük, inandırıcılık, kendine güven (Arıkan, 2004; Collins, Hanges ve Locke, 2004; Curth, 2011; Fuller ve Marler, 2009; Gartner, 1988; Gorman, Hanlon ve King, 1997; Korunka, Frank, Lueger ve Mugler, 2003; Rauch ve Frese, 2007; Shahhosseini, Kavousy, Shirsavar, ve Ardahaey, 2011; Shaver ve Scott, 1992; Stewart ve Roth, 2007; Utsch, Rauch, Rothful, ve Frase, 1999) olarak tanımlanmaktadır.

Girişimcilerin karakter özellikleri; içinde yaşadıkları aile yapıları aldıkları eğitim, içinde yaşadıkları çevre ve kültürel yapı gibi birçok faktörden etkilenmekte olup girişimcilik faaliyetlerinin oluşturulmasında etkilidir (Brodsky, 1993; Duchéneaut ve Orhan, 2000). Fırsatları görmek ve akılcı iş fikirleriyle risk almak, başarma ihtiyacı ve kontrol odağı rollerini eyleme dönüştürmek girişimcilerin işlevleridir. Üstlendikleri bu roller doğrultusunda azimli, istekli, kararlı, güçlü liderlik davranışı, yüksek düzeyde gelişim, analitik düşünme, yenilikçilik gibi girişimcilik karakter özellikleri inşasıyla (Aldrich, 1989; Brodsky,1993), hem kendileri için hem de girişimcilik faaliyetleri için entegre bir model geliştirmiş olurlar (Buttner ve Moore, 1997).

\section{ARAŞTIRMANIN METODOLOJISİ}

Araştırmanın metodolojisine, evrenine ve örneklemine, amacına ve hipotezlerine, araştırmanın verilerine ilişkin bilgilere, bulgular kısmında araştırmanın analizleri ve hipotezlerine yer verilmektedir.

\subsection{Araştırmanın Modeli ve Hipotezleri}

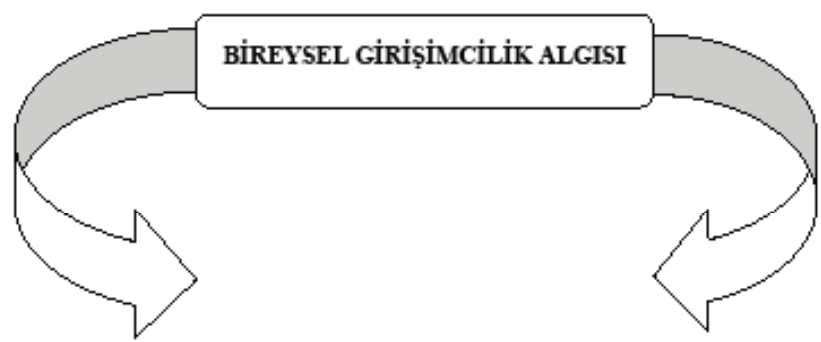




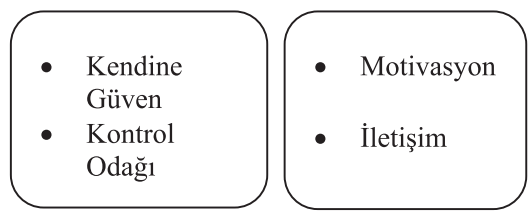

Şekil 1. Bireysel Girişimcilik Algısı Modeli

Araştırmanın hipotezleri aşağıda belirtilmektedir:

$\mathbf{H}_{1}$ : Kadın işletmecilerin Covid-19 öncesi girişimcilik algıları ile Covid-19 sürecinde girişimcilik algıları arasında anlamlı bir farklılık vardır.

$\mathbf{H}_{2}$ : Covid-19 öncesi ve Covid-19 sürecinde girişimcilik algıları arasındaki değişim kadın işletmecilerin faaliyet yaptıkları alana göre değişmektedir.

$\mathbf{H}_{3}$ : Covid-19 öncesi ve Covid-19 sürecinde girişimcilik algıları arasındaki değişim kadın işletmecilerin meslekî kıdemlerine göre değişmektedir.

$\mathbf{H}_{4}$ : Covid-19 öncesi ve Covid-19 sürecinde girişimcilik algıları arasındaki değişim kadın işletmecilerin öğrenim durumlarina göre değişmektedir.

\section{2. Çalışma Grubu}

Araştırmanın çalışma grubunu Kayseri ve Gaziantep ilinde faaliyet gösteren 250 kadın girişimci oluşturmaktadır. Araştırmada uygun örnekleme yöntemi kullanılmıştır. Yakın çevrede bulunan ulaşılması kolay, gönüllü katılımcı bireyler üzerinde yapılan örnekleme olarak tanımlanmıştır (Gravetter ve Forzano, 2012). Araştırma kapsamında 250 kadın girişimciye gönderilen çevrim içi ankete restoran, ev yemekleri, kafe, vb. (39); kuaför, güzellik salonu, vb. (15); eğitim merkezi, kreş, yurt, yaşlı bakım merkezi, vb. (76); spor salonu (13), temizlik hizmeti (53), bijuteri, aksesuar, takı, kozmetik, parfümeri, çeyizlik eşya satış, vb. (15) mikro işletme sahibi toplam 211 kadın girişimci dönüş yapmış ve bunlar araştırma kapsamında 
değerlendirilmiştir. Bu faaliyet alanlarının seçilmesinde pandemi sürecinde işletmelerin kısıtlamalar ve kapanmalardan etkilenmeleri faktörü önemli rol oynamıştır. Araştırma için gerekli izinler Hasan Kalyoncu Üniversitesi 22.04.2021-E.2104220003 nolu Evrak Tarih ve Sayısı ile alınmıştır. Anket için kullanılan ölçek izni ise elektronik ortamda yazarlardan izin alınarak kullanılmıştır.

\subsection{Araştırmanın Amacı}

Bu çalışmanın amacı Covid-19 küresel salgınında kadın girişimcilerin, pandemi öncesi ve pandemi sürecinde (pandeminin başlamasından 14 ay sonra) girişimcilik algılarının belirlenmesi ve karşılaştırılmasıdır. Bu bağlamda kadın girişimcilerin pandemi öncesi ve pandemi sürecinde girişimcilik algılarında (Kontrol Odağı, Kendine Güven, İletişim, Motivasyon boyutlarında) farklılık olup olmadığı test edilmiş, sonrasında kadınların demografik özelliklerine göre girişimcilik algılarında (alt boyutlarında) anlamlı değişim olup olmadığı araştırılmıştır.

\subsection{Araştırmanın Sinırlılıkları}

Araştırma kapsamında elde edilen veriler 2021 yılında çevrim içi ankete katılım sağlayan farklı sektörlerde işletmesi olan kadın girişimcilerin görüşleriyle sınırlıdır. Araştırma yapıldı̆̆ı süre içinde pandeminin devam ediyor olmasından dolayı çevrim içi anketle sınirlidir.

\subsection{Veri Toplama Aracı ve Analizi}

Araştırmada nicel araştırma yöntemi kullanılmıştır. Veri toplama aracı olarak çevrim içi anket kullanılmıştır. Anket iki bölümden oluşmaktadır. Anketin birinci bölümünde katılımcıların sosyodemografik bilgilerine ilişkin sorular yer almaktadır. İkinci bölümde, kadın katılımcıların Covid-19 öncesi ve sürecinde girişimcilik algılarıyla ilgili sorular bulunmaktadır. "Bireysel Girişimcilik Algı Ölçeği”, Yalçın İncik ve Uzun (2017) tarafından geçerlilik güvenilirlik çalışması yapılmış olup ölçeği kullanma izni yazarlardan elektronik 
ortamda izin alınarak araştırmada kullanılmıştır. Otuz bir maddeyi içeren ölçek, "Planlama" (6 madde), "Kontrol Odağı" (8 madde), "Kendine Güven" (6 madde), "İletişim" (4 madde), "Motivasyon" (4 madde) ve "Öz Disiplin" (3 madde) olmak üzere altı alt boyuttan oluşmaktadır. Altı boyutun oluşturduğu toplam varyans \%53,3 olarak bulunmuştur. Cronbach-alpha güvenirliği 0,92 olarak elde edilmiştir. İfadeler 5'li Likert ölçeğinde "kesinlikle katılmıyorum"dan "kesinlikle katılıyorum”a doğru 1'den 5’e kadar puanlanmıştır.

Bu araştırmada ölçek için SPSS programıyla yapılan Açımlayıcı Faktör Analizi ve Güvenilirlik Analizi'yle belirlenen iç tutarlılık ve geçerlilik puanları aşağıdaki tabloda gösterilmiş ve sonuçlar yorumlanmıştır. Ölçek ve boyutlarının güvenirlik analizi sonuçları Tablo 1'de, geçerlik analizi sonuçları Tablo 2'de verilmiştir.

\begin{tabular}{|l|c|c|}
\hline & Cronbach's Alpha & $\begin{array}{c}\text { Madde } \\
\text { sayısı }\end{array}$ \\
\hline Planlama & 0,355 & 6 \\
\hline Kontrol odağı & 0,694 & 8 \\
\hline Kendine güven & 0,684 & 6 \\
\hline İletişim & 0,826 & 4 \\
\hline Motivasyon & 0,920 & 4 \\
\hline Öz disiplin & 0,273 & 3 \\
\hline Genel & 0,860 & 31 \\
\hline
\end{tabular}

Tablo 1. Bireysel Girişimcilik Algı Ölçeği Güvenirlik Analizi Sonuçları

Tablodaki sonuçlara göre, Cronbach's Alpha katsayısı sırasıyla planlama alt boyutu için 0,355 ; kontrol odağ alt boyutu için 0,694 ; kendine güven alt boyutu için 0,684 ; iletişim alt boyutu için 0,826 ; motivasyon alt boyutu için 0,920 ve öz disiplin alt boyutu için 0,273 olarak hesaplanmıştır. Ölçeğin geneli için Cronbach's Alpha katsayısı 0,860 olarak hesaplanmıştır. Ölçeğin geneli için güvenirliğin yüksek olduğu söylenebilir. Ancak diğer taraftan planlama ve öz disiplin alt boyutları için güvenirlik son derece düşük çıkmıştır. Bunda katılımcıların yanıtlarının birbirine benzer olmasının etkili olduğu düşünülmektedir. Bu nedenle, bu çalışmaya özgü olarak ölçek 4 alt boyut üzerinden analiz edilmiştir. 


\begin{tabular}{|l|c|c|c|}
\hline & Öz değer & $\begin{array}{c}\text { Varyans } \\
\text { açılama } \\
\text { yüzdesi }\end{array}$ & $\begin{array}{c}\text { Birikimli } \\
\text { yüzde }\end{array}$ \\
\hline Kontrol odağı & 8,331 & 26,874 & 26,874 \\
\hline Kendine güven & 4,854 & 15,657 & 42,532 \\
\hline İletişim & 2,688 & 8,671 & 51,203 \\
\hline Motivasyon & 2,152 & 6,941 & 58,143 \\
\hline
\end{tabular}

Tablo 2. Bireysel Girişimcilik Algı Ölçeği Geçerlik Sonuçları

Tablodaki bilgilere göre, kontrol odağı alt boyutu öz değer 8,331; kendine güven alt boyutu öz değer 4,84; iletişim alt boyutu öz değer 2,688 ve motivasyon alt boyutu öz değer 2,152 olarak hesaplanmıştır. Buna göre öz değerler 1'den büyük olduğu için alt boyutların geçerliliklerinin iyi olarak değerlendirilebileceği söylenebilir. Ayrıca, kontrol odağı alt boyutu varyansın \%26,874'ünü, kendine güven alt boyutu varyansın \%15,657'sini, iletişim alt boyutu varyansın \%8,671'ini ve motivasyon alt boyutu varyansın \%6,941'ini açılamıştır. Bir ölçek için varyansın \%50-55 oranında açıklaması kabul edilmektedir. Buna göre, ölçek alt boyutları ölçeğin \%58,143’ünü açıkladığı için kabul edilebilir. Verilerin normal dağılımını kontrol etmede verilerin dağılımına ilişkin çarpıklık ve basıklık değerleri kontrol edilmiş ve sonuçları Tablo 3’te sunulmuştur.

\begin{tabular}{|l|c|c|}
\hline & Çarpıklık & Basıklık \\
\hline Bireysel Girişimcilik Algı Ölçeği & 0,06 & $-0,55$ \\
\hline
\end{tabular}

Tablo 3. Normallik Dağılımı Çarpıklık ve Basıklık Değerleri

Tabloya göre, ölçeğin çarpıklık değeri 0,06, basıklık değeri de $-0,55$ olarak hesaplanmıştır. Normal dağılımın belirlenmesinde dağılımın - 1,5 ile $+1,5$ arasında değer alması normal dağıldığını göstermektedir. Buna göre, ölçeğin dağılımı -1,5 ile +1,5 arasında olduğu için dağılım normal kabul edilmiş ve bu doğrultuda analizlerde parametrik testler yapılmıştır. 


\section{BULGULAR}

Araştırma kapsamında ilk olarak katılımcıları tanıtıcı bilgiler olarak sosyo-demografik bilgilere yer verilmiştir. Sonrasında ise katılımcıların pandemi öncesi ve pandemi sürecinde girişimcilik algiları karşılaştırmalı olarak incelenmiştir.

\subsection{Katılımeıları Tanımlayıcı Bulgular}

Kadın girişimcilerin medeni durum, yaş, öğrenim durumu, çocuk sayısı, kaç yıldır işletme sahibi olduğu, işletmenin faaliyet konusu ve çalışan sayısı gibi tanımlayıcı bilgilere yer verilmiştir.

\begin{tabular}{|l|c|c|}
\hline & N & $\%$ \\
\hline Medeni durum & & \\
\hline Evli & 149 & 70,6 \\
\hline Bekâr & 62 & 29,4 \\
\hline Toplam & 211 & 100,0 \\
\hline Yaş & 110 & \\
\hline 26-33 yaş & 101 & 52,1 \\
\hline 34-41 yaş & 211 & 100,9 \\
\hline Toplam & & \\
\hline Öğrenim durumu & 155 & 73,5 \\
\hline Lise mezunu & 56 & 26,5 \\
\hline Üniversite mezunu & 211 & 100,0 \\
\hline Toplam & & \\
\hline Çocuk sayısı & 62 & 27,0 \\
\hline Yok & 46 & 24,2 \\
\hline 1 çocuk & 103 & 48,8 \\
\hline 2-3 çocuk & 211 & 100,0 \\
\hline Toplam & & \\
\hline Kaç yıldır işletme sahibi olduğu & 50 & 23,7 \\
\hline 2 yıl & 115 & 54,5 \\
\hline 3 yıl & 46 & 21,8 \\
\hline 4 yıl & 211 & 100,0 \\
\hline Toplam & & \\
\hline İşletmenin faaliyet konusu & & \\
\hline
\end{tabular}




\begin{tabular}{|l|c|c|}
\hline & $\mathbf{N}$ & $\mathbf{\%}$ \\
\hline Restoran, ev yemekleri, kafe vb. & 39 & 18,5 \\
\hline Kuaför, güzellik salonu vb. & 15 & 7,1 \\
\hline $\begin{array}{l}\text { Eğitim merkez, kreş, yurt, yaşlı bakım merkezi } \\
\text { vb. }\end{array}$ & 76 & 36,0 \\
\hline Sppor salonu & 13 & 6,2 \\
\hline Temizlik hizmeti & 53 & 25,1 \\
\hline $\begin{array}{l}\text { Bijuteri, aksesuar, takı, kozmetik, parfümeri, } \\
\text { çeyizlik eşya satış vb. }\end{array}$ & 15 & 7,1 \\
\hline Toplam & 211 & 100,0 \\
\hline Çalışan sayısı & & \\
\hline 1 çalışan & 39 & 18,5 \\
\hline 2 çalışan & 91 & 43,1 \\
\hline 3 çalışan & 81 & 38,4 \\
\hline Toplam & 211 & 100,0 \\
\hline
\end{tabular}

Tablo 4. Katılımcıları Tanımlayıcı Bulgular

Tablo incelendiğinde, katılımcıların \%70,6'sının evli, \%29,4'ünün bekâr olduğu; \%52,1'inin 26-33, \%47,9'unun 34-41 yaş aralığında olduğu; \%73,5’inin lise, \%26,5’inin üniversite mezunu olduğu ve \%48,8'inin 2-3, \%27'sinin 1 çocuk sahibi olduğu ve $\% 24,2$ 'sinin çocuk sahibi olmadığı bulunmuştur. Katılımcıların \%54,5’inin 3 yıldır işletme sahibi olduğu, bunu \%23,7 oran ile 2 yıldır işletme sahibi olanların izlediği ve \%21,8'inin 4 yıldır işletme sahibi olduğu görülmüştür. İşletmelerin faaliyet konusu incelendiğinde, \%36's1nın eğitim ve sosyal hizmet merkezi gibi faaliyetler yürüttüğü, $\% 25,1$ 'inin temizlik hizmeti, \%18,5'inin restoran, ev yemekleri, kafe vb. faaliyetleri yürüttüğü bulunmuştur. Katılımcıların \%43,1'inin 2, \%38,4'ünün 3 ve \%18,5’inin 1 çalışanı bulunmaktadır.

\subsection{Katılımcıların Covid-19 Öncesi ve Covid-19 Sürecinde Girişimcilik Algılarına İlişkin Bulgular}

Katılımcıların pandemi öncesi ve pandemi sürecinde bireysel girişimcilik algılarına ilişkin bulgular Tablo 5’te yer almaktadır. 


\begin{tabular}{|c|c|c|c|c|c|c|}
\hline & & $\mathbf{N}$ & $\overline{\mathbf{x}}$ & Ss & $\mathbf{t}$ & $\mathbf{p}$ \\
\hline \multirow{2}{*}{$\begin{array}{l}\text { Bireysel girişim- } \\
\text { cilik algısı }\end{array}$} & Öncesi & 211 & 4,28 & 0,31 & \multirow[t]{2}{*}{87,56} & \multirow[t]{2}{*}{$0,00^{*}$} \\
\hline & Sürecinde & 211 & 2,79 & 0,23 & & \\
\hline \multirow{2}{*}{ Kontrol odağı } & Öncesi & 211 & 4,26 & 0,26 & \multirow[t]{2}{*}{73,87} & \multirow[t]{2}{*}{$0,00^{*}$} \\
\hline & Sürecinde & 211 & 2,52 & 0,33 & & \\
\hline \multirow{2}{*}{ Kendine güven } & Öncesi & 211 & 4,34 & 0,36 & \multirow[t]{2}{*}{76,01} & \multirow[t]{2}{*}{$0,00^{*}$} \\
\hline & Sürecinde & 211 & 3,29 & 0,33 & & \\
\hline \multirow{2}{*}{ İletişim } & Öncesi & 211 & 4,35 & 0,47 & \multirow[t]{2}{*}{60,18} & \multirow[t]{2}{*}{$0,00^{*}$} \\
\hline & Sürecinde & 211 & 3,06 & 0,40 & & \\
\hline \multirow{2}{*}{ Motivasyon } & Öncesi & 211 & 4,35 & 0,47 & \multirow[t]{2}{*}{56,02} & \multirow[t]{2}{*}{$0,00^{*}$} \\
\hline & Sürecinde & 211 & 2,90 & 0,43 & & \\
\hline
\end{tabular}

$\mathrm{p}<0,05$

Tablo 5. Katılımcıların Covid-19 Öncesi ve Covid-19 Sürecinde Bireysel Girişimcilik Algılarına İlişkin Bulgular

Katılımcıların pandemi öncesi bireysel girişimcilik algısı puan ortalamaları 4,28, pandemi sürecinde 2,79 olarak bulunmuştur. Katılımcıların pandemi öncesi ve sürecinde girişimcilik algıları arasında anlamlı bir fark vardır $(\mathrm{p}<0,5)$. Pandemi sürecinde katılımcıların bireysel girişimcilik algılarında azalma olduğu söylenebilir. Katılımcıların pandemi öncesi kontrol odağı alt boyutu puanları ortalaması 4,26, pandemi sürecinde 2,52 olarak hesaplanmıştır. Katılımcıların pandemi öncesi ve pandemi sürecinde kontrol odağı alt boyutu puanları arasında anlamlı bir fark tespit edilmiştir $(p<0,05)$. Buna göre, katılımcıların bireysel girişimciliğe ilişkin kontrol odaklarının pandemi sürecinde azaldığı düşünülebilir. Katılımcıların pandemi öncesi kendine güven alt boyutu puanları ortalaması 4,34; pandemi sürecinde 3,29 olarak bulunmuştur. Katılımcıların pandemi öncesi ve pandemi sürecinde kendine güven alt boyutu puanları arasında anlamlı bir fark saptanmıştır ( $p<0,05)$. Katılımcıların pandemi sürecinde bireysel girişimciliğge ilişkin kendine güvenlerinin düştügü ifade edilebilir. Katılımcıların pandemi öncesi iletişim alt boyutu puanları ortalaması 4.35, pandemi sürecinde 3,06 olarak bulunmuştur. Katılımcıların pandemi öncesi ve pandemi sürecinde iletişim alt boyutu puanları arasında anlamlı bir fark bulunmuştur $(\mathrm{p}<0,05)$. Buna göre, katılımcıların pandemi sürecinde bireysel girişimciliklerine ilişkin 
iletişimlerinin azaldığı söylenebilir. Katılımcıların pandemi öncesi motivasyon alt boyutu puanları ortalaması 4.35, pandemi sürecinde 2,90 olarak hesaplanmıştır. Katılımcıların pandemi öncesi ve pandemi sürecinde motivasyon alt boyutu puanları arasında anlamlı bir fark vardır $(\mathrm{p}<0,05)$. Katılımcıların pandemi sürecinde bireysel girişimciliklerine ilişkin motivasyonlarının azaldığı söylenebilir.

Katılımcıların pandemi öncesi ve pandemi sürecinde öğrenim durumlarına göre bireysel girişimcilik algılarına ilişkin bulgular Tablo 6'da sunulmuştur.

\begin{tabular}{|c|c|c|c|c|c|c|c|}
\hline & & $\begin{array}{l}\text { Öğrenim } \\
\text { Durumu }\end{array}$ & $\mathbf{N}$ & $\overline{\mathbf{x}}$ & Ss & $\mathbf{T}$ & $\mathbf{p}$ \\
\hline \multirow{4}{*}{$\begin{array}{l}\text { Bireysel giri- } \\
\text { şimcilik algısı }\end{array}$} & \multirow[b]{2}{*}{ Öncesi } & Lise mezunu & 155 & 4,29 & 0,32 & \multirow[t]{2}{*}{0,69} & \multirow[t]{2}{*}{0,48} \\
\hline & & $\begin{array}{l}\text { Üniversite } \\
\text { mezunu }\end{array}$ & 56 & 4,26 & 0,31 & & \\
\hline & \multirow[b]{2}{*}{ Sürecinde } & Lise mezunu & 155 & 2,80 & 0,23 & \multirow[t]{2}{*}{1,04} & \multirow[t]{2}{*}{0,30} \\
\hline & & $\begin{array}{l}\text { Üniversite } \\
\text { mezunu }\end{array}$ & 56 & 2,76 & 0,23 & & \\
\hline \multirow{4}{*}{ Kontrol odağ1 } & \multirow[b]{2}{*}{ Öncesi } & Lise mezunu & 155 & 4,27 & 0,27 & \multirow[t]{2}{*}{1,26} & \multirow[t]{2}{*}{0,20} \\
\hline & & $\begin{array}{l}\text { Üniversite } \\
\text { mezunu }\end{array}$ & 56 & 4,22 & 0,22 & & \\
\hline & \multirow[b]{2}{*}{ Sürecinde } & Lise mezunu & 155 & 2,53 & 0,33 & \multirow[t]{2}{*}{0,97} & \multirow[t]{2}{*}{0,32} \\
\hline & & $\begin{array}{l}\text { Üniversite } \\
\text { mezunu }\end{array}$ & 56 & 2,48 & 0,32 & & \\
\hline \multirow{4}{*}{ Kendine güven } & \multirow[b]{2}{*}{ Öncesi } & Lise mezunu & 155 & 4,35 & 0,36 & \multirow[t]{2}{*}{0,34} & \multirow[t]{2}{*}{0,73} \\
\hline & & $\begin{array}{l}\text { Üniversite } \\
\text { mezunu }\end{array}$ & 56 & 4,33 & 0,37 & & \\
\hline & \multirow[b]{2}{*}{ Sürecinde } & Lise mezunu & 155 & 3,30 & 0,33 & \multirow[t]{2}{*}{0,56} & \multirow[t]{2}{*}{0,57} \\
\hline & & $\begin{array}{l}\text { Üniversite } \\
\text { mezunu }\end{array}$ & 56 & 3,27 & 0,36 & & \\
\hline \multirow{4}{*}{ İletişim } & \multirow[b]{2}{*}{ Öncesi } & Lise mezunu & 155 & 4,36 & 0,48 & \multirow[t]{2}{*}{0,53} & \multirow[t]{2}{*}{0,59} \\
\hline & & $\begin{array}{l}\text { Üniversite } \\
\text { mezunu }\end{array}$ & 56 & 4,32 & 0,47 & & \\
\hline & \multirow[b]{2}{*}{ Sürecinde } & Lise mezunu & 155 & 3,07 & 0,41 & \multirow[t]{2}{*}{0,48} & \multirow[t]{2}{*}{0,62} \\
\hline & & $\begin{array}{l}\text { Üniversite } \\
\text { mezunu }\end{array}$ & 56 & 3,04 & 0,39 & & \\
\hline \multirow{4}{*}{ Motivasyon } & \multirow[b]{2}{*}{ Öncesi } & Lise mezunu & 155 & 4,36 & 0,48 & \multirow[t]{2}{*}{0,53} & \multirow[t]{2}{*}{0,59} \\
\hline & & $\begin{array}{l}\text { Üniversite } \\
\text { mezunu }\end{array}$ & 56 & 4,32 & 0,47 & & \\
\hline & \multirow[b]{2}{*}{ Sürecinde } & Lise mezunu & 155 & 2,92 & 0,43 & \multirow[t]{2}{*}{1,05} & \multirow[t]{2}{*}{0,29} \\
\hline & & $\begin{array}{l}\text { Üniversite } \\
\text { mezunu }\end{array}$ & 56 & 2,85 & 0,44 & & \\
\hline
\end{tabular}

$\mathrm{p}<0,05$

Tablo 6. Katılımcıların Öğrenim Durumlarına Göre Covid-19 Öncesi ve Covid-19 Sürecinde Bireysel Girişimcilik Algılarına İlişkin Bulgular 
Tablo değerlendirildiğinde, katılımcıların pandemi öncesinde ve pandemi sürecinde öğrenim durumlarına göre bireysel girişimcilik algıları arasında anlamlı bir farklılık yoktur ( $p>0,05)$. Aynı şekilde, ögrrenim durumlarına göre bireysel girişimcilik alt boyutlarına (kontrol odağı, kendine güven, iletişim, motivasyon) göre de farklılaşma yoktur ( $p>0,05)$. Katılımcıların pandemi öncesi ve pandemi sürecinde kaç yıldır işletme sahibi olduğuna göre bireysel girişimcilik algılarına ilişkin bulgular Tablo 7’de gösterilmiştir.

\begin{tabular}{|c|c|c|c|c|c|c|c|}
\hline & & $\begin{array}{c}\text { Kaç Yıldır } \\
\text { İşletme Sahibi } \\
\text { Olduğu }\end{array}$ & $\mathbf{N}$ & $\overline{\mathbf{x}}$ & Ss & $\mathbf{F}$ & $\mathbf{p}$ \\
\hline \multirow{6}{*}{$\begin{array}{l}\text { Bireysel } \\
\text { girişimcilik } \\
\text { algısı }\end{array}$} & \multirow{3}{*}{ Öncesi } & $2 \mathrm{yll}$ & 50 & 4,25 & 0,30 & \multirow{3}{*}{0,67} & \multirow[t]{3}{*}{0,51} \\
\hline & & $3 \mathrm{yll}$ & 115 & 4,28 & 0,32 & & \\
\hline & & $4 \mathrm{yll}$ & 46 & 4,33 & 0,32 & & \\
\hline & \multirow{3}{*}{ Sürecinde } & 2 yil & 50 & 2,76 & 0,23 & \multirow[t]{3}{*}{2,14} & \multirow[t]{3}{*}{0,11} \\
\hline & & $3 \mathrm{yll}$ & 115 & 2,78 & 0,23 & & \\
\hline & & $4 \mathrm{yll}$ & 46 & 2,85 & 0,23 & & \\
\hline \multirow{6}{*}{ Kontrol odağ } & \multirow{3}{*}{ Öncesi } & $2 \mathrm{yll}$ & 50 & 4,22 & 0,21 & \multirow[t]{3}{*}{1,19} & \multirow[t]{3}{*}{0,30} \\
\hline & & 3 yıl & 115 & 4,26 & 0,28 & & \\
\hline & & 4 yil & 46 & 4,30 & 0,24 & & \\
\hline & \multirow{3}{*}{ Sürecinde } & $2 \mathrm{yil}$ & 50 & 2,47 & 0,34 & \multirow[t]{3}{*}{2,53} & \multirow[t]{3}{*}{0,08} \\
\hline & & 3 yil & 115 & 2,50 & 0,33 & & \\
\hline & & $4 \mathrm{yll}$ & 46 & 2,61 & 0,30 & & \\
\hline \multirow{6}{*}{ Kendine güven } & \multirow{3}{*}{ Öncesi } & $2 \mathrm{yll}$ & 50 & 4,34 & 0,38 & \multirow[t]{3}{*}{1,21} & \multirow[t]{3}{*}{0,29} \\
\hline & & $3 \mathrm{yll}$ & 115 & 4,32 & 0,34 & & \\
\hline & & $4 \mathrm{yll}$ & 46 & 4,42 & 0,39 & & \\
\hline & \multirow{3}{*}{ Sürecinde } & $2 \mathrm{yll}$ & 50 & 3,29 & 0,35 & \multirow[t]{3}{*}{1,39} & \multirow[t]{3}{*}{0,25} \\
\hline & & 3 yil & 115 & 3,27 & 0,32 & & \\
\hline & & $4 \mathrm{yll}$ & 46 & 3,36 & 0,35 & & \\
\hline \multirow{6}{*}{ İletişim } & \multirow{3}{*}{ Öncesi } & 2 yıl & 50 & 4,30 & 0,46 & \multirow[t]{3}{*}{0,45} & \multirow[t]{3}{*}{0,63} \\
\hline & & 3 yıl & 115 & 4,35 & 0,48 & & \\
\hline & & $4 \mathrm{yll}$ & 46 & 4,39 & 0,49 & & \\
\hline & \multirow{3}{*}{ Sürecinde } & 2 yıl & 50 & 3,04 & 0,36 & \multirow[t]{3}{*}{0,12} & \multirow[t]{3}{*}{0,88} \\
\hline & & 3 yil & 115 & 3,06 & 0,42 & & \\
\hline & & $4 \mathrm{yil}$ & 46 & 3,08 & 0,42 & & \\
\hline \multirow{6}{*}{ Motivasyon } & \multirow{3}{*}{ Öncesi } & 2 yil & 50 & 4,30 & 0,46 & 0,45 & 0,63 \\
\hline & & $3 \mathrm{yll}$ & 115 & 4,35 & 0,48 & & \\
\hline & & $4 \mathrm{yll}$ & 46 & 4,39 & 0,49 & & \\
\hline & & $2 \mathrm{yll}$ & 50 & 2,86 & 0,44 & 0,89 & 0,40 \\
\hline & Sürecinde & $3 \mathrm{yll}$ & 115 & 2,89 & 0,43 & & \\
\hline & & $4 \mathrm{yll}$ & 46 & 2,97 & 0,43 & & \\
\hline
\end{tabular}

$\mathbf{p}<0,05$

Tablo 7. Katılımcıların Kaç Yıldır İşletme Sahibi Olduğuna Göre Covid-19 Öncesi ve Covid-19 Sürecinde Bireysel Girişimcilik Algılarına İlişkin Bulgular 
Tablodaki bilgilere göre, katılımcıların pandemi öncesinde ve pandemi sürecinde kaç yıldır işletme sahibi olduğuna göre bireysel girişimcilik algıları arasında anlamlı bir farklılık yoktur $(\mathrm{p}>0,05)$. Aynı şekilde, kaç yıldır işletme sahibi olduğuna göre bireysel girişimcilik alt boyutlarına (kontrol odağı, kendine güven, iletişim, motivasyon) göre de farklılaşma yoktur ( $p>0,05)$. Katılımcıların pandemi öncesi ve pandemi sürecinde faaliyet yaptıkları alana göre bireysel girişimcilik algılarına ilişkin bulgular Tablo 8'de verilmiştir.

\begin{tabular}{|c|c|c|c|c|c|c|c|}
\hline & & İşletme Faaliyet Alanı & $\mathbf{N}$ & $\overline{\mathbf{x}}$ & Ss & $\mathbf{F}$ & $\mathbf{p}$ \\
\hline \multirow{12}{*}{$\begin{array}{l}\text { Bireysel } \\
\text { girişim- } \\
\text { cilik } \\
\text { algısı }\end{array}$} & \multirow{6}{*}{ Öncesi } & Restoran vb. hizmetler & 39 & 4,31 & 0,33 & \multirow{6}{*}{0,84} & \multirow{6}{*}{0,52} \\
\hline & & Kuaför vb. hizmetler & 15 & 4,24 & 0,28 & & \\
\hline & & Eğitim ve sosyal hizmetler & 76 & 4,24 & 0,29 & & \\
\hline & & Spor salonu & 13 & 4,25 & 0,30 & & \\
\hline & & Temizlik hizmeti & 53 & 4,33 & 0,33 & & \\
\hline & & Kozmetik vb. hizmetler & 15 & 4,36 & 0,36 & & \\
\hline & \multirow{6}{*}{$\begin{array}{l}\text { Süre- } \\
\text { cinde }\end{array}$} & Restoran vb. hizmetler & 39 & 2,78 & 0,27 & \multirow{6}{*}{1,25} & \multirow{6}{*}{0,28} \\
\hline & & Kuaför vb. hizmetler & 15 & 2,77 & 0,17 & & \\
\hline & & Eğitim ve sosyal hizmetler & 76 & 2,80 & 0,23 & & \\
\hline & & Spor salonu & 13 & 2,70 & 0,18 & & \\
\hline & & Temizlik hizmeti & 53 & 2,78 & 0,24 & & \\
\hline & & Kozmetik vb. hizmetler & 15 & 2,91 & 0,25 & & \\
\hline \multirow{12}{*}{$\begin{array}{l}\text { Kontrol } \\
\text { odağ }\end{array}$} & \multirow{6}{*}{ Öncesi } & Restoran vb. hizmetler & 39 & 4,28 & 0,28 & \multirow{6}{*}{0,42} & \multirow{6}{*}{0,82} \\
\hline & & Kuaför vb. hizmetler & 15 & 4,25 & 0,25 & & \\
\hline & & Eğitim ve sosyal hizmetler & 76 & 4,23 & 0,23 & & \\
\hline & & Spor salonu & 13 & 4,25 & 0,19 & & \\
\hline & & Temizlik hizmeti & 53 & 4,28 & 0,28 & & \\
\hline & & Kozmetik vb. hizmetler & 15 & 4,30 & 0,31 & & \\
\hline & \multirow{6}{*}{$\begin{array}{l}\text { Süre- } \\
\text { cinde }\end{array}$} & Restoran vb. hizmetler & 39 & 2,49 & 0,38 & \multirow{6}{*}{1,77} & \multirow{6}{*}{0,11} \\
\hline & & Kuaför vb. hizmetler & 15 & 2,59 & 0,17 & & \\
\hline & & Eğitim ve sosyal hizmetler & 76 & 2,57 & 0,32 & & \\
\hline & & Spor salonu & 13 & 2,48 & 0,25 & & \\
\hline & & Temizlik hizmeti & 53 & 2,43 & 0,32 & & \\
\hline & & Kozmetik vb. hizmetler & 15 & 2,65 & 0,36 & & \\
\hline
\end{tabular}




\begin{tabular}{|c|c|c|c|c|c|c|c|}
\hline \multirow{12}{*}{$\begin{array}{l}\text { Kendine } \\
\text { güven }\end{array}$} & \multirow{6}{*}{ Öncesi } & Restoran vb. hizmetler & 39 & 4,33 & 0,35 & \multirow{6}{*}{0,96} & \multirow{6}{*}{0,44} \\
\hline & & Kuaför vb. hizmetler & 15 & 4,27 & 0,27 & & \\
\hline & & Eğitim ve sosyal hizmetler & 76 & 4,32 & 0,35 & & \\
\hline & & Spor salonu & 13 & 4,26 & 0,34 & & \\
\hline & & Temizlik hizmeti & 53 & 4,39 & 0,39 & & \\
\hline & & Kozmetik vb. hizmetler & 15 & 4,48 & 0,41 & & \\
\hline & \multirow{6}{*}{$\begin{array}{l}\text { Süre- } \\
\text { cinde }\end{array}$} & Restoran vb. hizmetler & 39 & 3,27 & 0,33 & \multirow{6}{*}{1,49} & \multirow{6}{*}{0,19} \\
\hline & & Kuaför vb. hizmetler & 15 & 3,21 & 0,31 & & \\
\hline & & Eğitim ve sosyal hizmetler & 76 & 3,29 & 0,34 & & \\
\hline & & Spor salonu & 13 & 3,14 & 0,28 & & \\
\hline & & Temizlik hizmeti & 53 & 3,33 & 0,35 & & \\
\hline & & Kozmetik vb. hizmetler & 15 & 3,44 & 0,33 & & \\
\hline \multirow{12}{*}{ İletişim } & \multirow{6}{*}{ Öncesi } & Restoran vb. hizmetler & 39 & 4,41 & 0,49 & \multirow{6}{*}{0,97} & \multirow{6}{*}{0,43} \\
\hline & & Kuaför vb. hizmetler & 15 & 4,26 & 0,45 & & \\
\hline & & Eğitim ve sosyal hizmetler & 76 & 4,27 & 0,45 & & \\
\hline & & Spor salonu & 13 & 4,30 & 0,48 & & \\
\hline & & Temizlik hizmeti & 53 & 4,41 & 0,49 & & \\
\hline & & Kozmetik vb. hizmetler & 15 & 4,46 & 0,51 & & \\
\hline & \multirow{6}{*}{$\begin{array}{l}\text { Süre- } \\
\text { cinde }\end{array}$} & Restoran vb. hizmetler & 39 & 3,09 & 0,46 & \multirow{6}{*}{0,87} & \multirow{6}{*}{0,50} \\
\hline & & Kuaför vb. hizmetler & 15 & 3,00 & 0,38 & & \\
\hline & & Eğitim ve sosyal hizmetler & 76 & 3,05 & 0,38 & & \\
\hline & & Spor salonu & 13 & 2,92 & 0,35 & & \\
\hline & & Temizlik hizmeti & 53 & 3,08 & 0,42 & & \\
\hline & & Kozmetik vb. hizmetler & 15 & 3,21 & 0,41 & & \\
\hline \multirow{12}{*}{$\begin{array}{l}\text { Motivas- } \\
\text { yon }\end{array}$} & \multirow{6}{*}{ Öncesi } & Restoran vb. hizmetler & 39 & 4,41 & 0,49 & \multirow{6}{*}{0,97} & \multirow{6}{*}{0,43} \\
\hline & & Kuaför vb. hizmetler & 15 & 4,26 & 0,45 & & \\
\hline & & Eğitim ve sosyal hizmetler & 76 & 4,27 & 0,45 & & \\
\hline & & Spor salonu & 13 & 4,30 & 0,48 & & \\
\hline & & Temizlik hizmeti & 53 & 4,41 & 0,49 & & \\
\hline & & Kozmetik vb. hizmetler & 15 & 4,46 & 0,51 & & \\
\hline & \multirow{6}{*}{$\begin{array}{l}\text { Süre- } \\
\text { cinde }\end{array}$} & Restoran vb. hizmetler & 39 & 2,94 & 0,44 & \multirow{6}{*}{1,78} & \multirow{6}{*}{0,11} \\
\hline & & Kuaför vb. hizmetler & 15 & 2,78 & 0,42 & & \\
\hline & & Eğitim ve sosyal hizmetler & 76 & 2,84 & 0,42 & & \\
\hline & & Spor salonu & 13 & 2,73 & 0,41 & & \\
\hline & & Temizlik hizmeti & 53 & 2,98 & 0,43 & & \\
\hline & & Kozmetik vb. hizmetler & 15 & 3,06 & 0,42 & & \\
\hline
\end{tabular}

$\mathrm{p}<0,05$

Tablo 8. Katılımcıların Faaliyet Yaptıkları Alana Göre Covid-19 Öncesi ve Covid-19 Sürecinde Bireysel Girişimcilik Algılarına İlişkin Bulgular 
Tabloya göre, katılımcıların pandemi öncesinde ve pandemi sürecinde işletme faaliyet alanına göre bireysel girişimcilik algıları arasında anlamlı bir farklılık yoktur ( $p>0,05)$. Aynı şekilde, işletme faaliyet alanına göre bireysel girişimcilik alt boyutlarına (kontrol odağı, kendine güven, iletişim, motivasyon) göre de farklılaşma yok$\operatorname{tur}(\mathrm{p}>0,05)$.

\section{Sonuç ve Öneriler}

Araştırmanın amacı kadın girişimcilerin Covid-19 öncesi ve Covid-19 sürecinde bireysel girişimcilik algısını belirlemek ve karşılaştırmaktır. Araştırmanın amacı doğrultusunda elde edilen temel sonuçlar özetlenerek aşağıda verilmiştir.

Kadın girişimcilerin \%70,6'sının evli, \%29,4'ünün bekâr olduğu; \%52,1'inin 26-33, \%47,9'unun 34-41 yaş aralığında olduğu; $\% 73,5$ 'inin lise, \%26,5’inin üniversite mezunu olduğu ve \%48,8'inin 2-3 , \%27,0'sinin 1 çocuk sahibi ve \%24,2'sinin çocuk sahibi olmadığı bulunmuştur. Katılımcıların \%54,5’inin 3 yıldır işletme sahibi olduğu, bunu \%23,7 oran ile 2 yıldır işletme sahibi olanların izlediği ve \%21,8'inin 4 yıldır işletme sahibi olduğu görülmüştür. İşletmelerinin faaliyet konusu incelendiğinde, \%36’sının eğitim ve sosyal hizmet merkezi gibi faaliyetler yürüttüğü, \%25,1'inin temizlik hizmeti, \%18,5'inin restoran, ev yemekleri, kafe, vb. faaliyetleri yürüttüğü bulunmuştur. Katılımcıların \%43,1'inin 2, \%38,4'ünün 3 ve \%18,5’inin 1 çalışanı bulunmaktadır.

Katılımcıların pandemi öncesi ve pandemi sürecinde girişimcilik algıları, bireysel girişimciliğe ilişkin kontrol odakları, bireysel girişimciliğe ilişkin kendine güvenleri, bireysel girişimciliklerine ilişkin iletişimleri ve bireysel girişimciliklerine ilişkin motivasyonları arasında anlamlı bir fark bulunmuştur. Girişimcilik algıları arasındaki en fazla fark motivasyon ve kontrol odağı arasında bulunmuştur. Pandemi sürecinin neredeyse tüm insanlar üzerinde yarattığı olumsuz psikolojik ruh hâli motivasyon düşüklüğüne sebep olmuş olabilir. Pandemi, girişimcilerin kendi iradesi dışında gelişen şartlara ve belirsizliğin artmasına sebep olarak kadın girişimcilerin 
kontrol odağı boyutunda da düşüşe sebep olmuş olabilir. Dolayısıyla, Covid-19 kadın girişimcilerin bireysel girişimcilik algıları ve boyutları üzerinde etkili olmuştur. Bu süreçten dolayı onların bireysel girişimcilik algılarının olumsuz etkilendiği söylenebilir.

$\mathrm{Bu}$ araştırmayla yaşamımızın gündeminde olan Covid-19 virüsünün sebep olduğu pandemi sürecinde, girişimci kadınların girişimcilik algılarını araştırmak hedeflenmiştir. Çalışmaya yönelik girişimcilik ve Covid-19 salgınıyla alakalı çalışmalara rastlanmış ancak Covid-19 sürecinde girişimci kadınların girişimcilik algılarına yönelik çok az çalışma bulunabilmiştir. Kadın girişimcilerin pandemi sürecinde girişimcilik algılarının değişiklik göstermesine ilişkin çalışmaların, özellikle kadın girişimciler (Manolova, Brush, Edelman ve Elam, 2020; Mathew, Deborah, Karonga ve Rumbidzai, 2020; Jaim 2020; Grandy, Cukier ve Gagnon, 2020) üzerine odaklanan araştırmalar, bu çalışmanın literatürünü ve bulgularını desteklemektedir.

Covid-19 öncesi girişimci kadın bireylerin karakter özelliklerine yönelik yapılan araştırmalardan elde edilen bulgular girişimci bireylerin; kontrol odağı (Brockhaus, 1980; Korunka vd., 2003), motivasyon (Collins vd., 2004; Johnson, 1990; Stewart ve Roth, 2007), iletişim (Gorman vd., 1997), planlama (McCarthy ve Leavy, 1999), kendine güven (Gartner, 1988) ve öz disiplin (Shahhosseini vd., 2011) gibi özelliklere sahip olduklarını, diğer bir ifadeyle, bu araştırmanın sonuçlarını destekler nitelikte olduğunu ortaya koymaktadır.

Pandeminin, araştırma kapsamına giren mikro ölçekli, yeni sayılabilecek 5 yılını tamamlamamış, işletme sahibi kadınların girişimcilik algılarını olumsuz yönde etkilediği görülmektedir. Kadın girişimcilere devlet desteğinin yanında STK'ların da destekleri bulunmaktadır (KAGIDER, 2021; KOSGEB b, 2020; Kedv, 2021). Ancak bu desteklerin arttırılması gerekmektedir. Bu desteklerin hem maddi hem de kriz yönetimi, stres yönetimi, e ticaret gibi ihtiyaca yönelik eğitimlerle sunulması önerilebilir. Bu araştırmanın daha sonra nitel usullerle gerçekleştirilmesinin gelecekteki çalışmalara yardımcı olacağı düşünülmektedir. 


\begin{tabular}{|c|c|}
\hline \multicolumn{1}{|c|}{ HİPOTEZLER } & $\begin{array}{c}\text { KABUL / RET } \\
\text { DURUMLARI }\end{array}$ \\
\hline $\begin{array}{c}\mathbf{H}_{1}: \text { Kadın işletmecilerin Covid-19 öncesi girişimcilik } \\
\text { algıları ile Covid-19 sürecinde girişimcilik algılları } \\
\text { arasında anlamlı bir farklılık vardır. }\end{array}$ & KABUL \\
\hline $\begin{array}{l}\mathbf{H}_{2}: \text { Covid-19 öncesi ve Covid-19 sürecinde girişimcilik } \\
\text { algıları arasındaki değişim kadın işletmecilerin } \\
\text { faaliyet yaptıkları alana göre değişmektedir. }\end{array}$ & RET \\
\hline $\begin{array}{l}\mathbf{H}_{3}: \text { Covid-19 öncesi ve Covid-19 sürecinde girişimcilik } \\
\text { algıları arasındaki değişim kadın işletmecilerin } \\
\text { meslekî kıdemlerine göre değişmektedir. }\end{array}$ & RET \\
\hline $\begin{array}{l}\mathbf{H}_{4}: \text { Covid-19 öncesi ve Covid-19 sürecinde girişimcilik } \\
\text { algıları arasındaki değişim kadın işletmecilerin } \\
\text { öğrenim durumlarına göre değişmektedir. }\end{array}$ & RET \\
\hline
\end{tabular}

Tablo 9. Hipotezlerin Kabul Ret Durumu

\section{Kaynakça}

Aldrich, H. (1989). Networking among women entrepreneurs. O. Hagan, C. Rivchun and D. Sexton (eds), Women-Owned Businesses, New York: Praeger, pp. 103-13.

Arat, N. (1996). Women's studies in turkey. Women's Studies Quarterly, 24(1/2), 400-411.

Arıkan, S. (2004). Girişimcilik: Temel kavramlar ve bazı güncel konular. Ankara: Siyasal Kitabevi.

Aşkın, E.Ö. ve Barış, S. (2016). Kadın istihdamında sosyal sermayenin etkisi: Tokat ilinde kadın girişimciler üzerine bir inceleme. Business and Economics Journal, 7(2), 63-82.

Bacq, S., Geoghegan, W., Josefy, M., Stevenson, R. ve Williams, T.A. (2020). The COVID-19 virtual idea blitz: Marshaling social entrepreneurship to rapidly respond to urgent grand challenges. Business Horizons. 63(6), 705-723.

Baumol, W. J. (1968). Entrepreneurship in economic theory. The American Economic Review, 58(2), 64-71.

Brockhaus, R.H. (1980). Risk taking propensity of entrepreneursi. Academy of Management Journal, 23(3), 509-502. 
Brodsky, M.A. (1993). Successful female corporate managers and entrepreneurs: Similarities and differences, Group \& Organisation Management, 18, 366-78.

Brush, C.G., De Bruin, A. ve Welter, F. (2009). Agender-aware framework for women's entrepreneurship. International Journal of Gender and Entrepreneurship, 1(1), 8-24.

Bowman, C. (1999). Action-led strategy and managerial selfconfidence. Journal of Managerial Psychology, 14(7/8), 558-568.

Buttner, E.H. ve Moore, D.P. (1997). Women's organizational exodus to entrepreneurship: Self-reported motivations and correlates with success. Journal of Small Business Management, 35(1), 34.

Carland, J.W., Hoy, F., Boulton, W.R. ve Carland, J.A.C. (1984). Differentiating entrepreneurs from small business owners: A conceptualization. Academy of Management Review, 9, 354-9.

Collins, C.J., Hanges, P.J. ve Locke, E.A. (2004). The relationship of achievement motivation to entrepreneurial behavior: A meta-analysis. Human Performance, 17(1), 95-117.

Cowling, M., Brown, R. ve Rocha, A. (2020). Did you save some cash for a rainy COVID-19 day? the crisis and smes. International Small Business Journal, 38(7), 593-604.

Curth, A. (2011). Mapping of teachers preparation for entrepreneurship education (ed. daniela ulicna). Final Report, Framework Contract No EAC 19/06, Dg Education and Culture, J 30258322.

Czarniawska-Joerges, B. ve Wolff, R. (1991). Leaders, managers, entrepreneurs on and off the organizational stage. Organization Studies, 12(4), 529-546.

Çelebi, N. (1993). Kadın girişimciliğini özendirme ve destekleme konusunda politikalar. kadını girişimciliğe özendirme ve destekleme paneli bildiriler ve tartışmalar. kadın ve sosyal hizmetler müsteşarlığı kssg müdürlüğü. Eğitim Serisi Yayın, No: 74: 35-42.

Duchéneaut, B. ve Orhan M. (2000). Les femmes entrepreneurs en france, paris: Séli arslan. Feeser, H.R. ve Dugan. K.W. (1989). Entrepreneurial motivation: A comparison of new venture creation. Academy of Management Review, 10(4), 696-706.

Fuller Jr, B. ve Marler, L.E. (2009). Change driven by nature: A meta-analytic review of the proactive personality literature. Journal of Vocational Behavior, 75(3), 329-345.

Forrester, W.R. ve Armen, T. (2010). Effects of personality on attitudes toward academic group work. American Journal of Business Education, $3(3), 39-46$. 
Gartner, WB. (1988). Who is an entrepreneur? Is the wrong question. American Journal of Small Business, 12(4), 11-32.

Gorman, G., Hanlon, D. ve King, W. (1997). Some research perspectives on entrepreneurship education, enterprise education and education for small business management: A ten-year literature review. International Small Business Journal, 15(3), 56-77.

Grandy, G., Cukier, W. ve Gagnon, S. (2020). (In)visibility in the margins: COVID-19, women entrepreneurs and the need for inclusive recovery. Gender in Management, 35(7-8), 667-675. https://doi.org/10.1108/GM07-2020-0207.

Gravetter, J. F. ve Forzano, L. B. (2012). Research methods for the behavioral sciences (4. Bas-kı). USA: Linda Schreiber-Ganster.

Hedefler için İş Dünyası Platformu, (2020). Covid-19 krizinin işletmeler üzerindeki etkileri- 2.anket (11-22 mayıs 2020) sonuç raporu. https:// tusiad.org/tr/basinbultenleri/item/10586-covid-19-krizinin-isletmeler uzerindeki-etkilerininanketsonuclari-aciklandi. (Erişim Tarihi: 15.05.2021).

Hisrich, R. D. ve Peters, M. P. (2002). Entrepreneurship, McGraw-Hill/Irwin, New York.

İlter, B. (2008). Girişimcilik sürecinde kadın girişimcilerin karşılaştıkları sorunların analizi: kagider örneği. Yayımlanmamış Doktora Tezi. Afyon Kocatepe Üniversitesi, Afyon.

Jaim, J. (2020). Exist or exit? Women business-owners in bangladesh during COVID-19. Gender, Work ve Organization. https://doi.org/10.1111/ gwao.12546.

Johnson, B.R. (1990). Toward a multidimensional model of entrepreneurship: The case of achievement motivation and the entrepreneur. Entrepreneurship Theory and Practice, 14(3), 39-54.

Kadın Emeğini Değerlendirme Vakfı, (KEDV). https://www.kedv.org.tr/ (Erişim Tarihi: 10.05.2021).

Kadın Girişimci Derneği, (KAGİDER). https://www.kagider.org/ (Erişim Tarihi: 10.05.2021).

Kahya, C. ve İmamoğlu, İ.K. (2015). Ekonomi okuryazarlığının girişimcilik niyeti üzerindeki rolü. International Journal of Social Science. 39: 139-156.

Koh, H.C. (1996). Testing hypotheses of entrepreneurial characteristics: A study of Hong Kong mba students. Journal of Managerial Psychology, $11,12-25$. 
Korunka, C., Frank, H., Lueger, M. ve Mugler, J. (2003). The entrepreneurial personality in the context of resources, environment and the startup process a configurational approach. Entrepreneurship Theory and Practice, 28(1), 23-42.

Küçük ve Orta Ölçekli İşletmeleri Geliştirme ve Destekleme İdaresi Başkanlığı, (KOSGEB) (2020a). https:/www.kosgeb.gov.tr/site/tr/genel/ detay/7426/kobilere-Covid19-kalkani-bakan-varank-kosgebin-3lukoruma-paketini-acikladi. 25 Mart 2020 (Erişim Tarihi: 10.05.2021).

Küçük ve Orta Ölçekli İşletmeleri Geliştirme ve Destekleme İdaresi Başkanlığı, (KOSGEB) (2020b). https://www.kosgeb.gov.tr/site/tr/genel/ detay/6878/kosgebden-kadinlara-pozitif-ayrimcilik (Erişim Tarihi: 20.05.2021).

Linan, F. ve Chen, Y. (2009). Development and cross-cultural application of a spesific instrument to measure entrepreneurial intentions. Entrepreneurship Theory and Practice. 33: 593-617.

Low, M.B. ve MacMillan, I.C. (1988). Entrepreneurship: past research and future challenges. Journal of Management, 14(2), 139-161.

Manolova, TS., Brush, CG., Edelman, LF. ve Elam, A. (2020). Pivoting to stay the course: How women entrepreneurs take advantage of opportunities created by the COVID-19 pandemic. International Small Business Journal, 38(6), 481-491.

Mathew, N., Deborah, I., Karonga, T. ve Rumbidzai, C. (2020). The impact of COVID-19 lockdown in a developing country: narratives of selfemployed women in Ndola, Zambia. Health Care for Women International, 41(11-12), 1370-1383. https://doi.org/10.1080/07399332.2020. 1823983.

McCarthy, B., ve Leavy, B. (1999). The entrepreneur, risk perception and change over time: A typology approach. Irish Business and Administative Research,19/20 (1), 125-141.

Mitchell, B.R. (1962). Abstract of british historical statistics, cambridge: Cambridge University Press, p. 60.

Organisation For Economic Co-Operation And Development. (2020), Education Responses To COVID-19: Embracing Digital Learning And Online Collaboration, OECD Policy Responses To Coronavirus (COVID-19). http://www.oecd.org/coronavirus/policy-responses/educationresponses-to-covid-19-embracing-digital-learning-and-onlinecollaboration-d75eb0e8/ (Erişim Tarihi: 15.05.2021).

Omar, A.R.C., Ishak, S. ve Jusoh, M.A. (2020). The impact of covid-19 movement control order on smes' businesses and survival strategies. Geografia-Malaysian Journal of Society and Space, 16(2), 139-150. 
Paksoy, H.M., Özbezek, B.D. ve Gül, M. (2019). Kişilik özellikleri ve sosyal sorumluluk bilincinin sosyal girişimcilik özelliklerine etkileri üzerine bir araştırma. Turkish Studies - Social Sciences,14(3), 973-1006. doi: 10.29228/TurkishStudies.22859.

Ratten, V. (2020). Coronavirus (Covid-19) and entrepreneurship: cultural, lifestyle and societal changes. Journal of Entrepreneurship in Emerging Economies. https://doi.org/10.1108/JEEE-06-2020-0163.

Rauch, A. ve Frese, M. (2007). Let's put the person back into entrepreneurship research: A meta-analysis on the relationship between business owners' personality traits, business creation, and success. European Journal of Work and Organizational Psychology, 16(4), 353-385.

Resmî Gazete (2021). Esnaf ve sanatkârlar ile gerçek kişi tacirlere koronavirüs salgını nedeni ile verilecek hibe desteği hakkında karar. https:// www.resmigazete.gov.tr/ 21 Mayıs 2021. (Erişim Tarihi: 21.05.2021).

Resmî Gazete (2017). Ulusal istihdam stratejisi (2014-2023) ve eylem planlarl (2017-2019).

https://www.resmigazete.gov.tr/eskiler/2017/07/20170707M1-1.pdf (Erişim Tarihi: 21.05.2021).

Rotter, J.B. (1966). Generalized expectancies for internal versus external control of reinforcement. Psychological Monographs, 80, 1-28.

Shahhosseini, A., Kavousy, E., Shirsavar, H.R. ve Ardahaey, F.T. (2011). Appointing the level of individual entrepreneurship of islamic azad university students. Asian Social Science, 7(1), 106-114.

Shaver, K.G. ve Scott, L.R., (1992). Person, process, choice: The psychology of new venture creation. Entrepreneurship Theory and Practice, 16(2), 23-45.

Stewart, Jr., W.H. ve Roth, P.L. (2007). A meta-analysis of achievement motivation differences between entrepreneurs and managers. Journal of Small Business Management, 45, 401-421.

Şeşen, H. ve Basım, H.N. (2012). Demografik faktörler ve kişiliğin girişimcilik niyetine etkisi: spor bilimleri alanında öğrenim gören üniversite öğrencileri üzerine bir araştırma. Ege Akademik Bakış, 12,21-28

Şekerler, H. (2006). Kadın girişimciler, karşılaştıkları sorunlar ve bu sorunlara yönelik çözüm önerileri. Yayımlanmamış Yüksek Lisans Tezi. Dumlupinar Üniversitesi, Kütahya.

T.C. Sağlık Bakanlığı. (2020). COVID-19 (SARS-CoV-2 Enfeksiyonu) rehberi, https://covid19bilgi.saglik.gov.tr/depo/rehberler/COVID-19 Rehberi. pdf. (Erişim Tarihi: 02.10.2020). 
T.C. Sağlık Bakanlığı. (2021). https://covid19.saglik.gov.tr/TR-68443/covid19-durum-raporu.html. (Erişim Tarihi: 19.05.2021).

Utsch, A., Rauch, A., Rothful, R. ve Frase, M. (1999). Who becomes a small scale entrepreneur in an post-socialistic environment: On the differences between entrepreneurs and managers in east germany. Journal of Small Business Management, 37(3), 31-42.

Yadav, V. ve Unni, J. (2016). Women entrepreneurship: Research review and future directions. Journal of Global Entrepreneurship Research, $6(12), 1-18$.

Yalçın İncik, E. ve Uzun, N. (2017). Bireysel girişimcilik algı ölçeği geçerlik ve güvenirlik çalışması. Mustafa Kemal Üniversitesi Sosyal Bilimler Enstitüsü Dergisi, 14(39), 471-485.

World Health Organization. (2020), Survey tool and guldance rapid, simple, flexible behavioural insights on COVID-19. Document Number: Who/ Euro:2020-696-40431-54222, (Erişim Tarihi: 19.05.2021). 